\title{
系統的シャフルを用いた並列型分枝限定法 —マルチプロセッサタスクスケジューリングへの応用
}

$\begin{array}{llllll}\text { 正員 } & \text { 近 } & \text { 藤 } & \text { 仁 } & \text { 志 } & \text { (東エ大) } \\ \text { 正 員 小 } & \text { 林 } & \text { 史 } & \text { 典 } & \text { (九エ大) } \\ \text { 非会員 } & \text { 原 } & & \text { 辰 } & \text { 次 } & \text { (東エ大) } \\ \text { 正員 } & \text { 武 } & \text { 平 } & \text { 信 } & \text { 夫 } & \text { (徳山高専) }\end{array}$

\section{Parallel Branch and Bound Method Using Systematic Shuffing - Application to Multiprocessor Task Scheduling}

Hitoshi Kondoh, Member (Tokyo Institute of Technology), Fuminori Kobayashi, Member (Kyushu Institude of Technology), Shinji Hara, Non-member (Tokyo Institute of Technology), Nobuo Takehira, Membr (Tokuyama College of Technology)

The most general technique that can be used to solve a wide variety of combinatorial extremumsearch problems, such as the task scheduling for parallel processing, is the branch-and-bound algorithm. However, since these problems are nondeterministic polynomial (NP)-complete, the solution derived within an appropriate searching time is not always optimal.

In this paper, from the standpoint of avoiding local minimum solutions, we propose a practical scheduler which searches a wide area of the search tree using plural searching strategies based on the latest starting time and performing a systematic shuffing of the priority list for node selections.

Our computer simulation results demonstrate that the systematic shuffing yields to dramatic acceleration in obtaining the candidate solutions. An application of the proposed scheduler to the simulation of the impact drop of a roll milling machine indicates that the total idle time of the processors can be decreased by a factor of ninety when compared to the conventional scheduling approachs. The observation of a mechanical manipulator control application reveales that the minimum number of processors for reaching the critical path length is five, with the conventional scheduling requiring seven.

キーワード：マルチプロセッシング，最適化問題，並列処理，分枝限定法，NP 困難

\section{1.まえがき}

デバイスの改良による計算機の高速化には限界があ るため, 近年, 並列処理でこれを補う研究が盛んに行 われている。しかし，タスクの割当問題は厳密に解け

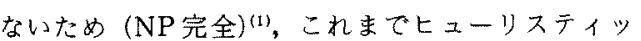
ク法やシミュレーティッドアニーリング法（以下， $\mathrm{SA}$ と略記)，また遺伝的アルゴリズム（以下，GA と 略記)など, 様々な近似解法が提案されてきだ(2)(3)。

笪学論C, 113 巻 3 号, 平成 5 年
$\mathrm{SA}$ ○A は自然界に見られる鼠適化原理をシミ一 レートしたもので，熱の励起や突然変異などの操作に より，局所解に陷りにくい特幑をもつ。しかし重複し た解候補安何度も探索したり，解がありそうもない領 域も探索するなど，探索效率は低い。

己机に対し，DF/IHS ${ }^{(4)}$ 法，遂次探索を行う分枝限 定法に，出口ノ一ドまでの最短時間に基づきタスクを 割当てる直接構成法を組合せたものである。これによ り, 解精度の高い上限値が探索の早期に得られ, 更に 
ヒューリスティィック徝をタスク番号に反映する簡素化 を図ることで,より多くの探索が行なえる特徴をも つ。しかしこれまでは, 最適解を逃すまいとするあま り，階乗オーダである部分問題をすべて探索し（局所 解に固執してしまい)，限られた時間を有効に利用で きない問題点もあった。

そこで本論文では，探索効率の高い分枝限定法に着 目し，最適解の導出よりも最悪ケースを抑えることを 主眼に，局所解にとらわれすぎない，広範囲の領域を 探索する実用的なスケジュラの構築を試みる。

まず，並列処理のテクニックを用い，複数の探索を 並列に行う。しかしその探索は長くは行わず，その局 所解近傍を探索したところで打ち切る。その後探索則 を変更し，再び探索を開始する。これを繰返すことで 徐々に探索範囲を別の領域に移動してゆく。本手法の 特徴は，探索領域のシフトを解精度の高い上限值の得 られる複数の挆索則から，徐々に広げてゆくところに ある。

スケジュラは，マルチタスクにより実現している。 実験はまずランダムに発生した仮想タスクグラフに 適用し，最悪ケースを抑える効果を確認する。次に圧 延インパクトドロップシミュレーション，执よびロボ ットアームの制御計算の二つの実問題に適用し，更に 解を更新できることを示す。特に後者は 1980 年に Luhが最初に报ってから，吉川，笠原と研究を重ね てきた問題であるが，これまで7台のCPUを用いな ければクリチカルパスに到達できなかったのに対し， 2 台少ない 5 台のCPUでこれを達成，しかもこれが この問題に扔ける最小CPU数であることがわかっ たo

以下，第 2 章で分枝限定法について述心，第 3 章で はシミュレーションを基に，幾つかの探索則について 考察する。次に第 4 章で, 探索領域の固執の問題を再 認識し，第 5 章で估，系統的シャフリングにより探索 領域を切換える手法を提案する。最後に第 6 章で，実 問題に適用した結果加ら本手法の有效性を考察する。

\section{2. ジョブショップスケジューリング問題}

〈2・1〉分枝限定法による解法とその性質ここ で报う問題は，先行制約をもち，各々タスク長の異な る非分割 (nonpreemptive) なタスク集含を, 能力の 等しい複数の機械で処理する, 処理時間最小化問題て ある。な战，以下タスク数を $n$ ，処理する機械の数を $m$ とする。

この問題の最適解を有限時間内に求めることのでき る唯一の手法は分枝限定法である。これは，最適解を
与える可能性がないと明らかになった部分問題を省く （枝刈）などの工夫によって，もともと階萧オーダの 計算量を指数オーダに下げたり，指数関数の次数を下 げる効果がある(12)。しかし，分枝限定法は基本的に しらみつぶしである。結局，タスク数が少し増えれば 膨大な探索時間を要し，探索の打切りを前提としなけ ればならない。

以下に分枝限定法の基本的性贅を挙げておく。

〔性望 1]解精度の高い上限值が，探索の早期に 見つかるほど，単位時間内に探索する範囲が広がる。

〔性質 2〕処理を開始してしばらくは解候補をあ る程度連続して出力するが，次第にその閶隔は层がっ ていきそのうち出力しなくなる(出力硬直を起こ す)。

[性質 3]深さ優先の分枝限定法はバックトラッ クが下から進むため，深さの浅い探索ノ一ドほどバッ クトラックが起きにくい。

また(性質 3)より，打切りを前提とした分枝限定法 には，“探索の早期に選択した浅いノードに間違った 組合せがあった場合，最後まで再考慮できない”とい う問題がある。

〈2・2〉優先順位リストをもつ分枝限定法 分枝 限定法の各探索ステージでは，割当てるべきタスクが レディタスクの中から順に選ばれるが，〔性質1〕よ り，この順序が特に重要である。そのため，レディ夕 スクにヒューリスティック值を与え，値の高いものか ら順に選ぶ手法がとられる。これを探索前にあらかじ め計算できる範囲にとどめれば，探索は高速になるの で,この優先順 (番号) をリストにとり，これをもと にレディタスクを選ぶ手法が考えられる。

\section{3. 探索則とその評価}

〈3.1〉探 索 則以下に㑑先順位リストの决定 法（探索則）について述へる。ここては探索前に決定 できるものにとどめ，これをタスク番号の考え方(4)に 反映し、すべて同じスケジュラで探索する。

（1）最遅開始時刻優先法第一に各タスクの最 迤開始時刻 (latest starting time) の早い順とする。 これは有向本のタスタグラフの最適アルゴリズム(6)に 用いられたものである。しかし任意形状のタスクグラ フにおいては、同レベルのタスクが複数ある場合の㑑 先順位を一意に決定できないため，この選択を俱ると 非常に悪い解しか得られない欠点がある。そこで，同 じ場合は別の条件走付加する。以下にその条件を示 す。このなかで最初の条件（タスク次数の大きい順） についてはタスクスケジュールに対して有効であると 
系統的シャフルを用いた分枝限定法

表 1 単一探索則による解の分布

Table 1. Distribution of the solutions (idle time) for the various single search strategies.

\begin{tabular}{r|r|r|r|r|r|r|r|r}
\hline 条件 & \multicolumn{4}{|c|}{$C_{1}$} & \multicolumn{4}{c}{$C 2$} \\
\hline 梠索則 & $H 1$ & $H 2$ & $H 3$ & $H 4$ & $H 1$ & $H 2$ & $H 3$ & $H 4$ \\
\hline $0 \sim 1$ & 24 & 10 & 23 & 2 & 0 & 0 & 0 & 0 \\
$2 \sim 3$ & 11 & 13 & 12 & 5 & 1 & 0 & 1 & 0 \\
$4 \sim 7$ & 22 & 37 & 27 & 7 & 1 & 4 & 3 & 0 \\
$8 \sim 15$ & 13 & 13 & 14 & 20 & 8 & 11 & 11 & 0 \\
$16 \sim 31$ & 8 & 8 & 8 & 9 & 33 & 37 & 33 & 0 \\
$32 \sim 63$ & 9 & 8 & 7 & 9 & 30 & 23 & 31 & 0 \\
$64 \sim 127$ & 11 & 9 & 7 & 6 & 17 & 17 & 14 & 0 \\
$128 \sim$ & 2 & 2 & 2 & 48 & 10 & 8 & 7 & 100 \\
\hline
\end{tabular}

$H 1:$ LO, H2:LF, H3:LM, H4:MO

いう報告がなされている(4) しかし著者らは，以下の どの探索則が最適であるかを決定することは, 局所最 適解への固執に活かならないと考える。

(i ) 夕スク次数の大きい䐓（以下，LOと呼ふ） ノードの次数 (order) とはタスクグラフにおける直 後の後続夕スク数を意味する。これは $m=2$ のときの 最適アルゴリズム(7)に用いられているもので， $m>2$ のときにも比較的良い解を導出することが調べられて औ. ${ }^{(4)}$

(ii) 余裕時間の少ない順 (以下, LFと呼ぶ) 余裕時間 (floating time) は， $m$ が十分大きいとき, クリチカルパス長を崩さずに変更できるタスクの実行 開始時刻の幅をいう。この時間の短いものを優先して 選べば,クリチカルパスを崩す確率の高いタスクを優 先して配置する意味がある。

（iii） 乱数順（以下. LM と呼ぶ）最遅開始時 刻が同じ場合乱数で選ぶ。根拠は何もないが，上の二 つ以外のノードが選ばれる。

（2）モンテカルロ法 各タスクは初めから乱数 によって選㤁（以下，MOと呼ぶ)。この手法に完全 に頼ることは閣題があるが，付加的に用いれば解の収 束を速めることがある。

〈3・2〉 各探索則の評価タスクグラフは乱数に より先行関係を決定した。条件は以下のつで，をれ ぞれ 100 個ずつ計 200 個である。この問題では， $m$ が少ないとき(3以下)に梳下限関数が良い値を出し， $m$ が多いとき(7以上)にはクリチカルパス八の到達率 が増す。従って，タスクグラフの発生条件にこれを含 めない上うにする。条件の一つ(C1) は, 外数 50, 夕スク長 1 300のうちから乱数で選び, 先行夕 スク数最大 2 を 4 台の機械に割当てる問題を探索時間 (CPU夕イム) 10 分間で処理するもの。もう一つ (C2) は, 夕スク数 100 , 夕スク長 $1 \sim 300$, 先行夕
表 2 同一タスクグラフに対する解の莁の分布 Table 2. Distribution of the differences between solutions for the same tast graph.

\begin{tabular}{|c|c|c|c|c|c|c|}
\hline 条件 & \multicolumn{3}{|c|}{$C 1$} & \multicolumn{3}{|c|}{$C_{2}$} \\
\hline 比較 & A & B & C & A & B & C \\
\hline $128 \sim$ & 0 & 0 & 1 & 0 & 0 & 0 \\
\hline $64-127$ & 0 & 2 & 3 & 1 & 1 & 0 \\
\hline $32 \sim 63$ & 3 & 4 & 5 & 5 & 3 & 0 \\
\hline $16 \sim 31$ & 2 & 2 & I & 12 & 17 & 0 \\
\hline $8 \sim 15$ & 4 & 3 & 2 & 7 & 4 & 0 \\
\hline $4 \sim 7$ & 7 & 7 & 2 & 15 & 14 & 0 \\
\hline $2 \sim 3$ & 0 & 0 & 0 & 0 & 0 & 0 \\
\hline $0 \sim 1$ & 0 & 0 & 0 & 0 & 0 & 0 \\
\hline 0 & 63 & 74 & 4 & 39 & 48 & 0 \\
\hline$-1 \sim 0$ & 0 & 0 & 0 & 0 & 0 & 0 \\
\hline$-3 \sim-2$ & 21 & 8 & 10 & 0 & 0 & 0 \\
\hline$-7 \sim-4$ & 0 & 0 & 4 & 8 & 5 & 0 \\
\hline$-15 \sim-8$ & 0 & 0 & 9 & 4 & 1 & c \\
\hline$-31 \sim-16$ & 0 & 0 & 5 & 4 & 4 & c \\
\hline$-63 \sim-32$ & 0 & 0 & 2 & 3 & 3 & c \\
\hline$-127 \sim-64$ & 0 & 0 & 8 & 2 & 0 & i \\
\hline-128 & 0 & 0 & 44 & 0 & 0 & 95 \\
\hline
\end{tabular}

A : LO-LF, B : LO-LM, C : LO-MO

スク数最大 2 を台の機械に割当てる問題をCPU夕 イム 3 分間で処理するものである。

表 1 は機械の非実働時間をそのまま 20 累乗スケー ルで度数分布表にしたものである。優先順位を考慮せ ずに探索した MO と比較して，LO，LF，LMはいず れも良好な結果が得られている。LO，LF，LMは一 兒同じような探索則に見えるが，それぞれ膨大な数の 局所部分問題を周囲にもち，(性質 2)より解の出力硬 直がしばしば起るため，規模の大きな問題では異なる 探索則と考えるべきである。特に，探索早期に良い上 限値が見つかりやすい最遅開始時刻優先則では, 最初 からほとんど解を更新しないまま探索時間を費やす。

表 2 は同一夕スタグラフに刘する解の差を示したも ので，例えばLOーLF㹥LOで得られたものから LF のそ机を引いたものである。従って十方向はLFが， そのタスクグラフに対しては，優位であったことを示 す。表 1, 表 2 上りLM の成績が良く，LOやLFの 近傍にだけ解があるとは限らないことがわかる。ま た，問題の規模によってはMOが良いケースも少な くなく，場合によっては，最遅開始時刻優先則だが 良いのではないこともわかる。

以上より，マクロに最遅開始時刻系の探索則が良い が，ミクロにはタスクグラフに依存し，どんなタスク グラフにも適した探索則岵存在しないと結論づけるこ とができる。これは，最漣開始時刻優先は例えば巡回 セールスマン問題でいう最近都市優先則に似て扔り, 
大まかには良い解を出すものの，整数最適化問題であ るため，結局は細かい調整をしなければ最適解は求め られないのと同じ理由と考えられる。

\section{4. 局所最適解への固執の回避}

次に局所解に固執しない観点から，あらかじめ与え られた探索時間を分割し，それぞれ異なる探索則で探 索してみる。ここでは，複数の探索則を同時に適用す る方法と，シャフリンダにより各探索則を順次切り換 えてゆく方法について述へる。

$\langle 4 \cdot 1\rangle$ 複数探索則 (性質 1) 加 , 複数の探索 則のどれを先に行なうかで解に差が出るため, 各探索 則を同時に実行し，プロセス間通信によって，上限值 を共有しながら探索する方法を採用する。このような 方法では，一つが精度の良い上限值を与えると，ほか もそれを用いて探索範囲を限定することができ，シー ケンシャルに切換えを行う場合に比べ探索効率が良 い。これは $p$ 台で処理してp倍以上の領域を探索で きることから，異常加速あるいは加速効果などと呼ば れる ${ }^{\{5\}(20)}$ 。

さてここでは, LOと $\mathrm{LF}(H 5), \operatorname{LO} と \mathrm{LM}(H 6)$, $\mathrm{LO}$ と $\mathrm{MO}(H 7)$ ，扔よび $\mathrm{MO}$ と $\mathrm{MO}(H 8)$ について シミュレーションしてみる。タスクグラブは前回と同 じものを用いた。結果表 3 に示可。

これより，C 1 の 7 とH8, 执よ゙C 2 の 5 とH6では，それぞれの探索則で得られなかったもの がお互いに補い合い，最悪ケースを揤える形で改善さ れている。その他に拈いては改善されているとはいえ ないものの，著しい悪化は兒られない。

改善されたケースを見ると，C1では MOを混ぜ たものがよいが, 逆にC2では最遅開始探索則を組 合せた弫うがよい。

この結果は表 2 からも推測できるが, 前者は比較的
簡単な問題であり，探索領域が狭くなるため，LO， LF，LM は和互いに近すぎ，領域が重複しているの に対し，MO梳度に離れた領域を探索したものと考 えられる。逆に後者では MOは極めて悪く, LO, LF, LM が適度に離れた领域を探索している。すな わち，並列探索を行う際には，探索則を選択する必要 があり，特にその近傍の度合が重要である。

〈4・2〉リストのシャフリング【性質2〕より, 探索を開始してしばらくすると出力硬直が起こる。そ こで，最後に解候補を出力してからある期間（探索 数：s）次の解候補が得られなくなったところで，リ ストを切り換えてみる。

リストの生成は $\mathrm{GA} や \mathrm{SA}$ にられるように，物理 モデルをシミンレートすることも考えられるが,ここ では，あらかじめ記憶して扔いた初期りストを毎回シ ヤフル（筆にランダムに要素を交換）して用いる。実 験はLOとLF (H9), LOとMO (H 10), それに MOとMO ( $H$ 11) の組合せについて行った。結果 を表 4 に示す。これより，シャフリングは著しい改善 効果があり，C1でほとんどが1桁以内に到達した。

ここでは $=50,000$ としたが，sは小さいほど多く

表 3 複数探索則に上る解の分布

Table 3. Distribution of the solutions for the various plural search strategies.

\begin{tabular}{r|r|r|r|r|r|r|r|r}
\hline \multicolumn{1}{c|}{ 条件 } & \multicolumn{5}{|c|}{$C_{1}$} & \multicolumn{4}{|c}{$C 2$} \\
\hline 探䇣則 & $H 5$ & $H 6$ & $H 7$ & $H 8$ & $H 5$ & $H 6$ & $H 7$ & $H 8$ \\
\hline $0 \sim 1$ & 24 & 24 & 28 & 4 & 0 & 0 & 0 & 0 \\
$2 \sim 3$ & 8 & 8 & 12 & 6 & 1 & 1 & 1 & 0 \\
$4 \sim 7$ & 22 & 23 & 23 & 17 & 3 & 2 & 0 & 0 \\
$8 \sim 15$ & 16 & 15 & 16 & 20 & 9 & 8 & 5 & 0 \\
$16 \sim 31$ & 8 & 8 & 13 & 15 & 43 & 41 & 36 & 0 \\
$32 \sim 63$ & 9 & 9 & 6 & 5 & 23 & 25 & 34 & 0 \\
$64 \sim 127$ & 11 & 11 & 1 & 3 & 14 & 14 & 18 & 0 \\
$128 \sim$ & 2 & 2 & 1 & 30 & 7 & 9 & 6 & 100 \\
\hline
\end{tabular}

$H 5:$ LOLF, $H 6$ : LOLM, $H 7:$ LOMO, $H 8:$ MOMO

表 4 シャフリングによる解の分布

Table 4. Distribution of solutions in case of shuffling.

\begin{tabular}{|c|c|c|c|c|c|c|c|c|c|c|c|c|}
\hline \multirow{3}{*}{$\begin{array}{c}\frac{\text { 条件 }}{\text { 探索則 }} \\
s\end{array}$} & \multicolumn{3}{|c|}{$\mathrm{Cl}$} & \multicolumn{9}{|c|}{$\mathrm{C} 2$} \\
\hline & \multirow{2}{*}{$\frac{H g}{50,000}$} & \multirow{2}{*}{$\begin{array}{r}H 10 \\
50,000 \\
\end{array}$} & \multirow{2}{*}{$\begin{array}{r}H 11 \\
50,000\end{array}$} & \multicolumn{3}{|c|}{$\mathrm{H9}$} & \multicolumn{3}{|c|}{$H 10$} & \multicolumn{3}{|c|}{$H 11$} \\
\hline & & & & 50,000 & 30,000 & 10,000 & 50,000 & 30,000 & 10,000 & 50,000 & 30,000 & 10,000 \\
\hline $0 \sim 1$ & 49 & 45 & 39 & 0 & 1 & 0 & 0 & 0 & 0 & 0 & 0 & 0 \\
\hline $2 \sim 3$ & 39 & 40 & 36 & 1 & 2 & 7 & 1 & 2 & 7 & 0 & 0 & 0 \\
\hline $4 \sim 7$ & 11 & 14 & 24 & 11 & 19 & 34 & 4 & 17 & 19 & 0 & 0 & 0 \\
\hline $8 \sim 15$ & 0 & 0 & 0 & 26 & 37 & 39 & 16 & 28 & 37 & 0 & 0 & 4 \\
\hline $16 \sim 31$ & 0 & 0 & 0 & 48 & 36 & 20 & 53 & 45 & 35 & 0 & 1 & 30 \\
\hline $32 \sim 63$ & 0 & 0 & 0 & 13 & 5 & 0 & 18 & 8 & 2 & 1 & 13 & 48 \\
\hline $64 \sim 127$ & 0 & 0 & 0 & 1 & 0 & 0 & 8 & 0 & 0 & 8 & 31 & 11 \\
\hline $128 \sim$ & 1 & 1 & 1 & 0 & 0 & 0 & 0 & 0 & 0 & 91 & 55 & 7 \\
\hline
\end{tabular}

H9: LOLFS, H 10:LOMOS, H 11: MOMOS 
の切換老を行う。そこでC2については，3種類 $(50,000,30,000,10,000)$ 変えてみた。

結果より，シャフリングはどの場合にも有効で, 同 じ探索則の近傍をいつまでも探索するより，広く浅く 探索するほうがよいことがわかる。また，タスクグラ フの規模によらず最遅開始時刻䯭先則を淈ぜたほう が，良い結果を得ることができる。これはシャフリン グにMOの効果があるため, 最遅開始時刻優先則近 傍をうまく探索できるためである。

\section{5.リストの系統的シャフル}

〈5・1〉系統的シャフルの必要性ここれまでの結 果を整理し，知見をまとめておく。

（1）探索則を幾つか用意して，そのすべてを並列 に処理すれば，加速効果も手伝って解は良くなる。た たし，並列探索の規模はタスクグラフに依存するの で，場合によっては，小さな間題に大きな並列システ ムを用いてしまう問題もある。

（2）初期探索則には最遅開始時刻優先則を用いれ ば，早期に良質の上限值が得られ，〔性質 1〕より探索 の效率が上がる。

（3）最迤開始時刻優先近傍の複数探索は良い解を 導出するが，その近傍の度合は近すぎても遠すぎても 効率を悪くする。従って，問題の規模によって有効な 探索則の組合せを変えてやる必要がある。しかし，こ れを先見的に決定する方法は一般には困難である。

(4) LMの成績が良いことから，リ大トは単に LO，LF，LM 乱数を用いて少し変更して作っても 効果がある。これは，[性質 3]に起因する探索机の上 方のステージが再考慮できない問題を，シャフリング で解決できることを示している。

(5) MOが早期に良好な上限值を導出することも あるので，MOの混入もときに解の収束を速める効果 がある。もちろん MO は悪い探索則となる可能性か 高いため，長く探索する必要はなく，また偶然できた 一つでなく他の可能性も繰返し選択したほうがよい。

（6）切換之は，表40結果挔上び[性筫 2]より， 探索早期にはしばしば行ったほうがよい。しかし，偨 索が進むにつれて上限值の解精度が良くなるため, 次 第に頻度を下げるべきである。

これらの条件をすべて満足するような系統的なシャ フルを行なうことができれば，単にシャフリングを行 うよりも更に効率的な探索が行える。

そこで，最遅開始時刻優先探索則と一部 $\mathrm{MO}$ を初 期探索に用い，以後徐々に乱数でそれを切り換えるこ とで探索領域を拡大してゆく。更に，切換えのタイミ
ングも以下のように段階的に変化させる方法が考えら れる。これにより，広い範囲の規模の夕スクグラフに 対して効果的なスケジュラが構築できる。

〈5・2〉系統的シャフルを用いたスケシュラ

$s$ 最小数は夕スク数nだけすれば少なくとも1国 探索できるため, 初期值は $s:=s_{0}$ (ここで, $s_{0}$ はn 以上の小さい値) とし，以後探索のたびにs:=ns( $>1$ )で更新する。

（1）最後の解候補を得てからs個のステージを探 索しても次の候補が得られなかったときはをの探索則 による探索を打ち切る。

（2）リストの種類に応じて，次のようにリストを 作り直し，再び探索を開始する。

(i) 最遈開始時刻偠先探索則のとき初期りス トをシャフリングして作る。 $s:=\eta s$

(ii) MOのとき 乱数により全〈新しいりスト 在作る。 $s:=s_{0}$

(3) 処理は次のいずれかの条件を満足したとき終 了方。

(i) 一つのスケジュラが探索木を読み切った。こ のとき親プロセスは，探索ノード数 〔sとなっている ことで判断できる。

(ii) 処理を開始してある期間（例えばCPU time で10分など) 調バた。

DF/IHSを並列化したPDF/IHSも提案されてい る(21)が，探索本のどこで分割するかについての考察 はなされていない。また, 本手法は局所解に固執しな い観点から，階采オーダで広がる多くの CP/MISF 解近傍の部分問題を捨て去る点で大きく巽なってい る。それとも関連して，本手法は探索の重複検査を行

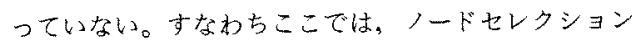
をいかに早くしてもNP完全な問題での探索木の読 みきり估不可能であり, 結局良い上限值による下限関 数での部分問題の限定が重要であるという立場をとつ ている。事実，表4で示したとおり，ほとんどすべて

表 5 提案手法に上る解の分布 Table 5. Distribution of solutions for the proposed method.

\begin{tabular}{c|c|c}
\hline 条件 & $C 1_{1}$ & $C 2_{2}$ \\
\hline $0 \sim 1$ & 53 & 6 \\
$2 \sim 3$ & 41 & 10 \\
$4 \sim 7$ & 5 & 40 \\
$8 \sim 15$ & 0 & 40 \\
$16 \sim 31$ & 0 & 4 \\
$32 \sim 63$ & 0 & 0 \\
$64 \sim 127$ & 0 & 0 \\
$128 \sim$ & 1 & 0 \\
\hline
\end{tabular}

電学論C, 113 巻 3 号, 平成 5 年 
のケースで短期間に良い解が得られている。

〈5・3〉シミュレーションによる評価 ここでは 前述の四つの探索則 LO, LF, LM, MO を初期探索 則とした。用いたコンピャータは，SunのSPARC stationで, $\eta=1.15$ ，シャフリングにおけるリストの 要素の交換回数は $0.1 n$ 回である。結果を表 5 に示す。 これより，最悪ケースを抑える形で解の分布が更に上 にシフトすることがわかる。なお，C1の128以上に ある一つのタスクグラフは最適解である。

また，同一探索時間（全プロセスの総和）で更に解 を更新することを加速効果とすれば，表 1 の結果と比 較して，少なくともC1で約60\%，C2では約 $90 \%$ がこれに硋当する。

\section{6. 実システムにおける評価}

笠原らが行っている，マルチナロセッサのタスクス ケジューリングの二つの例輗, 圧延機のインパクトド ロップシミュレーション(16) とロボットアーム制御計 算(17)を再実験してみた。探索時間は全プロセスの合 計で10分とした。

表 6 に压延機のインパクトドロップシミュレーショ ンの処理結果を示す。文献(16)では $m=4,6,70$ 上 きにやや精度が悪く，最適解からの相対誤差は10\% 程度残つたと報告されている。例えば， $m=4$ の場令 の非実働時間はLO法では 4017 clockであったが, これはスケジュール長の $48 \%$ の時䦤に相当する。こ 礼が本手法の適用により，45 clock（スケジュール長 の0.6\%)になった。このように，スケジュール長で 10\%の䛊差でも，CPUの利用率からみると大きなス ケジュール誤差であることがわかる。

表 7 にLuh(9)，吉壮(10)，笠原(17)らの行ったロボッ トアーム制御計算に適用した結果を示す。この問題も 既にほぼ最適解に到達しており，スケジュール長に対 する改善の余地はあまりない。それでも本手法を用い

表 6 压延機インパクトドロップ Table 6. Solutions for the roll milling machine.

\begin{tabular}{c|rr|rr}
\hline CPU & \multicolumn{2}{|c|}{ LO } & \multicolumn{2}{|c}{ 提案手法 } \\
\hline 1 & 29159 & $(0)$ & 29159 & $(0)$ \\
2 & 14975 & $(791)$ & 14583 & $(7)$ \\
3 & 9754 & $(103)$ & 9742 & $(67)$ \\
4 & 8294 & $(4017)$ & 7301 & $(45)$ \\
5 & 6053 & $(1106)$ & 5853 & $(106)$ \\
6 & 5429 & $(3415)$ & 4905 & $(271)$ \\
7 & 5004 & $(5869)$ & 4595 & $(3006)$ \\
8 & 4434 & $(6313)$ & 4434 & $(6313)$ \\
\hline
\end{tabular}

ることにより，やや相奶䛊差の残っていた $m=5$ およ び 6 のときに最適解を, また $m=4$ の問題でも解を更 に更新できた。

一方，CPUの非实働時間の立場加ら考えるとこ二 れまでクリチカルパスの到達に7台のCPUを要して いたのに対し，本手法ではこれを 5 台で到達，CPU2 台尔のコストの削減に成功している。

図 1 は 5 台のときの探索過程，図 2 はそのときの曼 適解である。図 1 から，LOは罗初に比較的良い上限 值（局所最適解）を得たことにより出力硬直の状態に 陷っているが，本手法では，系統的シャフルによっ て, 探索早期に良筫の上限値が次々と得られ，その後 徐々に広範囲の探索に移行し, 効率的な探索が行われ ていることがわかる。

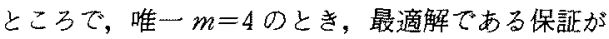
得られていない。しかしこのとき非実働時間は 1.49 である。すなわち，1台あたり $0.3725(1.49 \div 4)$ でありこれを最適解から引いた值 6.2075 がクリチ カルパス長 5.69 より大きいことから，この問題にお けるクリチカルパス到達の最小 CPU 数は 5 であるこ

表 7 ロボットアーム制䇝

Table 7. Solutions for the mechanical manipulator.

\begin{tabular}{c|c|c|c|cr}
\hline CPU & Luh & 吉汌 & \multicolumn{2}{|c|}{ 篮原 } & \multicolumn{2}{|c}{ 提案手法 } \\
\hline 1 & 25.04 & 25.04 & 24.83 & 24.83 & $(0)$ \\
2 & - & - & 12.42 & 12.42 & $(0.1)$ \\
3 & - & 10.41 & 8.43 & 8.43 & $(0.46)$ \\
4 & - & - & 6.59 & 6.58 & $(1.49)$ \\
5 & - & - & 5.86 & 5.69 & $(3.62)$ \\
6 & 9.70 & 9.67 & 5.73 & 5.69 & $(9.31)$ \\
7 & - & - & 5.69 & 5.69 & $(15.00)$ \\
\hline
\end{tabular}

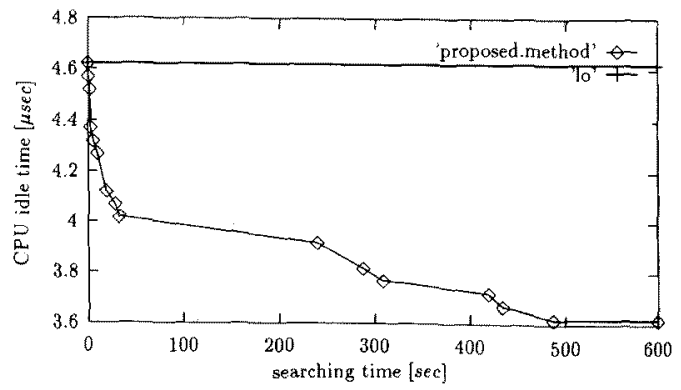

図 1 ロボットアーム制御の探甞過程 (cpu 5 台) Fig. 1. Search process for the mechanical manipulator control application (five processors).

T. IEE Japan, Vol, 113-C, No. 3, '93 

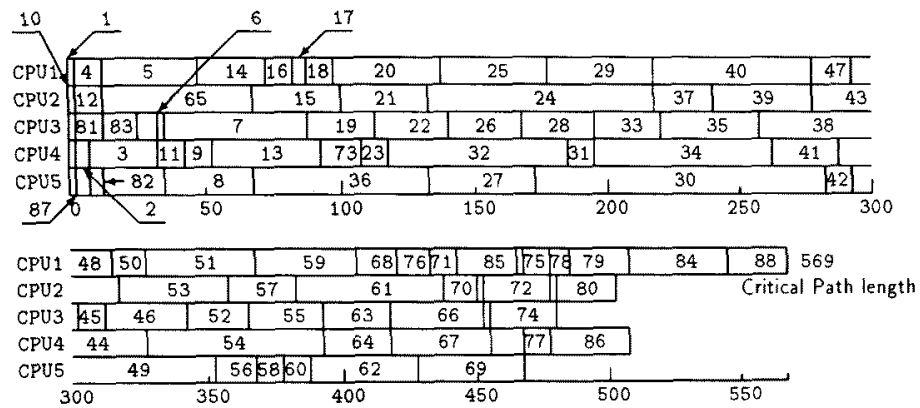

図 2 図 10 最適解

Fig. 2. Optimal solution for Fig. 1 .

表 8 挆索則とシャフリンダ

Table 8. Solutions for the various strategies.

\begin{tabular}{|c|c|c|c|c|}
\hline 問題 & \multicolumn{2}{|c|}{ 生延機 } & \multicolumn{2}{|c|}{ ロボット } \\
\hline $3+711 \geq 7$ & 無 & 有 & 無 & 南 \\
\hline LO & 4017 & 273 & 4.62 & 3.92 \\
\hline LOLF & 4017 & 85 & 4.62 & 3.62 \\
\hline LOLM & 4017 & 273 & 4.62 & 3.62 \\
\hline LOMO & 457 & 45 & 4.62 & 4.02 \\
\hline MOMO & 877 & 45 & 11.32 & 3.62 \\
\hline 提㕵手法 & & 45 & & 3.62 \\
\hline
\end{tabular}

とがわかる。

表 8 は各探索則における違いをCPUの非実働時間 で示したものである。压延機の場合では MOが良く， 最遅開始時刻優先則近傍に解がなったことを示してい る。また、シャフリングにより探索は著しく加速さ れ，LOに対して90分の1になっている。これはシ ヤフリングがMOとしての要素をもつためである。 一方，ロボットア一ムの場合ではMOの解から，最 遅開始時刻優先則近傍に良い解をもつことがかかる。 この場合もシャフリングにより著しい探索の加速がみ られるが、これは(性質3〕により問題となっていた上 方ノードの交換が行われたためてある。

\section{7.むす}

複数探索則をもつスケジュラに系統的なシャフリン グを施すことで，探索を加速するスケジュラを構築し た。GAやSAが広い範团から動的に局所最適解八探 索範囲を絞ってりく方式であるのに対し，本手法で は, 先天的に良いことがわかっている樷荤開始時刻優 先則近傍から探索範围を徐々に広げてゆく方法をと る。これにより探索効率の良い高精度の上限㯖が早期 に得られ，行枝限定法の効率を上げながら，局所解に
固執しない物理もデル近似法の特徴を融合できた。

実際にこれを乱数で生成したタスクグラフに適用し た結果，広い範囲で最悪ケースを抑えられることが確 認できた。ままた，压延機インパクトドロップシミュレ ーションおよじロボットアーム制御計算の実問題に適 用した結果，これまでCPU数によって生じていた解 精度のばらつきをなくすことができ，後者ではクリチ カルパス長に到達する最小CPU 数が 5 であることが 拣証できた。

(平成 4 年 6 月 22 日受付)

$$
\text { 文献 }
$$

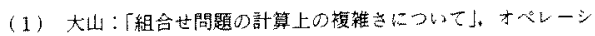
ヨンスりサーサ, No.7.427 (昭 54)

(2) S. Kirkpatrick, C. D. Gelatt \& Jr., M. P. Vecchi : "Optimization by Simulated Annealing", Science, 220. No. 4598 , 671 (1983)

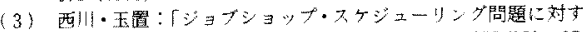

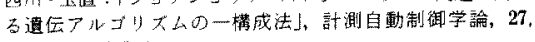
No. 5.593 (平 3)

(4)笠原・成田：「マルチプロせッサスケシュリング問題に対する 春用的な最適及び近似アルコりスム」, 信学諳、J67-D, 792 (路 59-7)

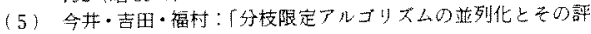
㑣与，同上，J62-D, 403 (昭 54-6)

(6) T.C.Hu: "Parallel Sequencing and Assembly Line Prob lem". Oper. Res.. No. 9, 841 (1961)

(7) E. G. Coffman \& R. L. Graham: "Optimal Scheduling for Two-Processor Systems". Acia. Informatica, 1, No. 3, 200 (1972)

(8) Guo-jie Li, Benjamin \& W. Wah: "Coping with Anomalies in Parallel Branch-and-Bound Algorithms", IEEE Trans. Comput., C-35, No. 6, 568 (1986)

(9) Luh \& Lin.: "Scheduling of Parallel Computer for a Computer-Controlled Mechanical Manipulator". IEEE Trans. SMC, SMC12, No. 2, 214 (1982)

(10) 声川:「口ボットームの動的制御のたすの蓝列演算方式に

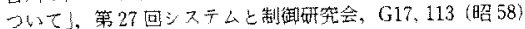

(11) Ossama Ibrahim El.Dessouki \& Wing H. Huen: "Dis tributed Enumeration on Between Computers", IEEE Trans. Comput. C-29, No.9, $818(1980)$

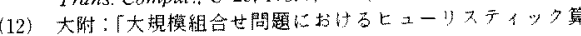
法], 信学鿁, 4, 416 (昭 50)

(13) C. V. Ramamoorthy, K. M. Chandy \& Mario I. Gonzalez

電学論 $C, 113$ 巻 3 号, 平成 5 年 
"Optimal Scheduling Strategies in a Muliprocessor System", IEEE Trans. Comput.. C-21. No. 2, 137 (1972)

(14) Benjamin W, Wah, Guo-jie Li \& Chee Fen Yu: "Multiprocessing of Combinatarial Search Problems", ibid., No. 1, 93 (1985)

(15) Benjamin W. Wah, Y.W. Eva Ma: "MANIP-A Multicomputer Architechture for Solving Combinatorial Extremum-Search Problems", ibid., C-33, No. 5, 377 (1984)

（16）笠原・安井・幸村・甲斐・成田：「マルチプロセッサ・スケシ ューリング・アルゴリズムを用いた連続システム・シミュレ ーションの並列処理」，信学技報, EC84-38 (昭 59)

（17）笠原・安井・幸村・甲斐・成田：「マルチプロセッサ・スケシ ユーリング・アルゴリズムを用いたロボット・アーム制御計 算の並列処理」, 同上, EC84-39 (昭 59)

(18) Robert G. Babb II : "Parallel Processing with Large-Grain Data Flow Techniques", IEEE Comput., No. 7, 55 (1984)

(19) Boontee Kruatrachue \& Ted Lewis: "Grain Size Determination for Parallel Processing", IEEE Software, No. 1, 23 (1988)

(20) Ten-Hwang Lai \& Sartaj Sahni: "Anomalies in Parallel Branch-and-Bound Algorithms", Communications ACM, No, 6, 594 (1984)

（21）笠原・伊藤・田中・伊藤：「実行時間最小マルチプロセッサス ケジューリング問題に対する並列最適化アルゴリズム」, 信 学論, J74-D1, 755 (平 3-11)

（22）川口・真栄田・増山：「非同期式並列分枝限定アルゴリズム! 同上, J74-D1，23 (平 3-1)

\section{付 録}

実験は，TCP/IPによるプロセッサ間通信を利用し て実現した。スケジュラは一つの親プロセス（以下， PPR) と, 複数の子プロセス (CPR) から構成され る。PPR と CPRの間はソケットにより結ばれ，ネッ トワーク上の複数の EWS で分割処理することもでき るし，1台でマルチタスク処理することも，またその 両方を混在することも可能である。

PPR は CPR から上限値の候補を受け取り，最良の 上限值を CPR に提供する。また CPR は探索が終了 した場合, PPRから次の探索リストを受け取り, 新 たな探索を行なう。このようにPPR は上限値とリス トを管理するスーパバイザという構成である。なお， このような非同期式分枝限定アルゴリズムにおけるプ ロセッサ間のブロードキャストについては文献(22)に 詳しい。著者らは同様のスケジュラを，共有メモリー を用いても，またシリアルリンクで結ばれたトランス ピュータ上でも実現している。

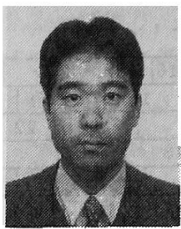

近藤仁志(正員)

昭和 60 年長岡技術科学大学大学院修 士課程修了。同年徳山工業高等専門学校 助手，同講師を経て，平成 2 年東京工業 大学助手。マルチプロセッサシステム, スケジューリングなどの研究に従事。電子情報通信学会, 計測自動制御学会会䝿。

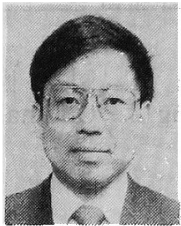

小林 史 典 (正員)

昭和 55 年東京工業大学大学院博士課 程修了。同年長岡技術科学大学助手, 同 助教授を経て, 平成元年九州工業大学助 教授。工学博士。現在, Stanford大学 客員研究員。回転機制御，信号処理などに與味をもつ。電 子情報通信学会, IEEE 会員。

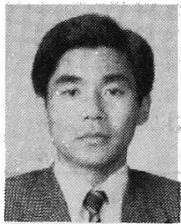

\section{原辰 次 (非会員)}

昭和 51 年東京工業大学大学院修士課 程修了。同年日本電信電話会社人社。 55 年長岡技術科学大学助手。59 年東京工 業大学助教授, 平成 4 年同教授。工学博 士。63 年〜平成元年カナダ Waterloo 大学客員研究員。口 バスト制御，ディジタル制御に関する研究に従事。計測自 動制御学会, 情報処理学会, 電子情報通信学会, IEEE 会員。

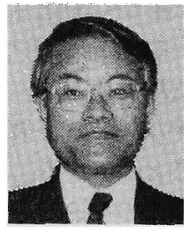

武平信夫(正員)

昭和 40 年山口大学電気工学科卒業。 同年同大学助手, 50 年同工業短期大学 講師を経て, 52 年徳山工業高等専門学 校助教授。現在，同教授。工学博士。56 年〜 57 年アメリカ・テネシー大学客員研究員。渦電流の諸 応用の研究に従事。電子情報通信学会, 計測自動制御学 会, 日本非破壊検査協会会員。 